\title{
STUDY ON THE VALUE OF A MEDIUM RESERVOIR STORAGE CAPACITY (CASE STUDY: KARALLOE RESERVOIR)
}

\author{
Widandi Soetopo $^{1}$, Lily Montarcih Limantara ${ }^{1}$, Agustina Pagatiku ${ }^{1}$ \\ ${ }^{1}$ Water Resources Engineering Department, Universitas Brawijaya, Malang 65145, Indonesia \\ email: wid31835@yahoo.co.id
}

\begin{abstract}
In this article, the value of storage capacity of a medium sized Karalloe reservoir is discussed. Together with an uncontrolled weir, the Karalloe reservoir is supplying an irrigation area. The purpose of the study is to estimate the value of reservoir storage capacity at the various storage states and at different dependable inflow levels. The Linear Programming model is used to optimize the irrigation benefit for various storage capacity and various dependable inflow levels. The results are used to estimate the values of storage capacity at various conditions. The results show that for inflow of the dry year, there is no value for the additional storage capacity. But for inflow of the wetter years, there are significant values for adding more storage capacity.
\end{abstract}

Keywords: value of storage capacity, medium reservoir

\section{INTRODUCTION}

Generally, a large sized irrigation area is supplied by one or more river. In an appropriate site, a weir is constructed to divert the streamflow to the irrigation area. If there is a possibility to build a reservoir, then it can increase the size of the total annual irrigated area to be served because the water from the surplus periods can be transferred to the deficit periods (dry spells) by utilizing its storage room to retain the surplus water.

Accordingly, the size of storage capacity is the principal asset of a reservoir. The larger is the storage capacity, the more valuable is the reservoir. Still, this valuable asset can be significantly reduced by the inflow of sediments $[1,2,3,4]$. The presence of dry spells in the series of streamflow actually heighten the value of the storage capacity. However, there is a limit where further addition of storage capacity do not have any benefit.

More reservoir storage capacity is always demanded in the developing region with growing population $[5,6,7]$. When a reservoir is operated with the optimal release rule and there are still a lot of spillout, it is the indication that more storage capacity is desired. At the same time, it is also the sign that the storage capacity has a high value. In this case, any additional storage capacity will bring significant increase in irrigation benefit. This condition occurs when the inflow is high during the wet seasons and it is low during the corresponding dry seasons, but on average the annual inflow is relatively high (in other words, it is the wet years). At the lower inflow, the increment in irrigation benefit will be also lower. At a certain value of storage capacity, there is no more increment in irrigation benefit. The purpose of this study is to estimate the value of storage capacity of the Karalloe reservoir at various of storage capacity and at various dependable inflow levels.

\section{MATERIAL AND METHODS}

To allow the study to be conducted properly, a medium sized irrigation 
reservoir in a river is selected. This reservoir, together with a diversion weir in another river, is slated to provide water for an irrigation area in the downstream.

\subsection{The location of study}

The medium sized reservoir to be used in this study is the Karalloe reservoir which is located in the Gowa Regency of South Sulawesi Province, Indonesia. The reservoir is slated to supply the Kerala Irrigation area to the downstream in the Jeneponto Regency. The Kerala Irrigation Area is also supplied by the Kerala Weir. The system of the Karalloe reservoir and the Kerala Weir can be seen in the Figure 1.

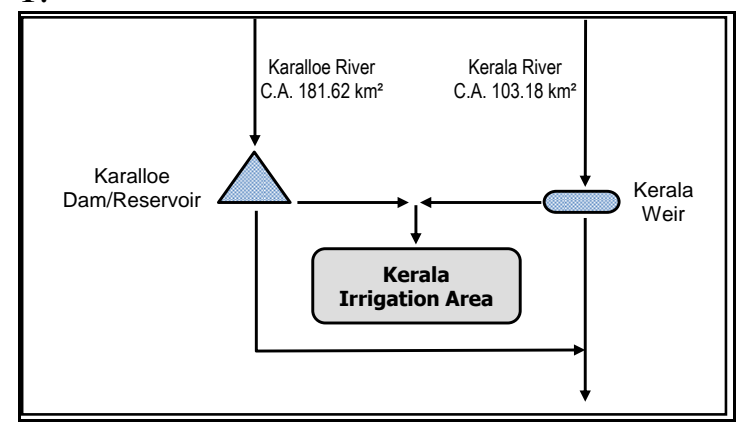

Figure 1. Karalloe Reservoir - Kerala Weir system

As can be seen in the Figure 1, there are two suppliers for the Kerala Irrigation Area. The first supplier is the Kerala Weir in the Kerala River with a catchment area of $103.18 \mathrm{~km}^{2}$. The Kerala Weir have not any storage capacity for reservoir operation. The second supplier is the Karalloe Reservoir with a catchment area of $181.62 \mathrm{~km}^{2}$.

\subsection{The system of Karalloe-Kerala}

The Karalloe Reservoir has the total storage capacity of 39.28 million $\mathrm{m}^{3}$ and the dead storage capacity of 11.02 million $\mathrm{m}^{3}$, therefore its active storage capacity is 28.26 million $\mathrm{m}^{3}$. In the system of Karalloe-Kerala, the Kerala Irrigation Area is directly supplied by the Kerala Weir using the discharge of the Kerala River. To supplement the supply of Kerala, a Karalloe Reservoir is to be built in the Karalloe River. Using the active storage capacity of 28.26 million $\mathrm{m}^{3}$, the Karalloe Reservoir can be operated optimally to fill the gaps in the water supply of the Kerala Weir.

The Kerala Irrigation Area is to be cultivated for 3 cropping seasons annually. Each cropping season is 4 months long and divided into 8 half-month periods. Therefore, there are 24 halfmonth periods annually. The two sources of water are also obliged to supply a predetermined amount of municipal water demand in the downstream area.

\subsection{The optimization models}

The optimization model for the reservoir operation to be used is the Linear Programming model [8, 9, 10]. The objective function on the reservoir operation optimization is to maximize the total irrigation benefit of the 3-cropping season annually. The constraints are the system of equation for water balance of the reservoir operation annually. In all, there are 95 equations and non-equation. The optimization is done for 6 active storage capacities and 4 conditions of inflow dependability. The Linear Programming optimization model is formatted in accordance with the MSExcel 2010, with the mathematical model is presented in the follow.

The Objective Function: Maximize $\mathrm{C}_{1} \cdot \mathrm{A}_{1}$ $+\mathrm{C}_{2} \cdot \mathrm{A}_{2}+\mathrm{C}_{3} \cdot \mathrm{A}_{3}$

With $\mathrm{C}_{\mathrm{i}}$ is the unit area benefit of season $\mathrm{i}$, and $\mathrm{A}_{\mathrm{i}}$ is the irrigation area of season $\mathrm{i}$.

Constraint of Reservoir Water Balance: $S_{i}$ $+\mathrm{I}_{\mathrm{i}}=\mathrm{S}_{\mathrm{i}+1}+\mathrm{O}_{\mathrm{i}}+\mathrm{P}_{\mathrm{i}}$ (24 constraints)

With $S_{i}$ is reservoir storage at the beginning of period $\mathrm{i} ; \mathrm{I}_{\mathrm{i}}, \mathrm{O}_{\mathrm{i}}$, and $\mathrm{P}_{\mathrm{i}}$ are inflow, outflow, and spillout in period $\mathrm{i}$; and $\mathrm{S}_{\mathrm{i}+1}$ is reservoir storage at the end of period $i$.

Constraint of Irrigation Water Supply: $\mathrm{O}_{\mathrm{i}}$ $+T_{i}=A \cdot R_{i}+B_{i}(24$ constraints $)$

With $\mathrm{A}$ is the irrigation area of the corresponding season; $\mathrm{T}_{\mathrm{i}}, \mathrm{R}_{\mathrm{i}}$, and $\mathrm{B}_{\mathrm{i}}$ are the additional water supply from weir, unit irrigation area water requirement, and municipal water requirement in period $i$. 
Table 1. The Benefit of Storage Capacity

\begin{tabular}{clllll}
\hline & Active & Q 26 \% & Q 50.7 \% & Q 75.3 \% & Q 97.3 \% \\
\cline { 2 - 5 } No. & $\begin{array}{l}\text { Storage } \\
\left(10^{6} \mathrm{~m}^{3}\right)\end{array}$ & Benefit & Benefit & Benefit & Benefit \\
& $\left(10^{6} \mathrm{rp}\right)$ & $\left(10^{6} \mathrm{rp}\right)$ & $\left(10^{6} \mathrm{rp}\right)$ & $\left(10^{6} \mathrm{rp}\right)$ \\
\hline 1 & 28.26 & 216,535 & 144,648 & 127,231 & 107,897 \\
\hline 2 & 28.50 & 218,158 & 145,794 & 128,377 & 107,897 \\
\hline 3 & 28.75 & 219,850 & 146,988 & 129,571 & 107,897 \\
\hline 4 & 29.00 & 221,541 & 148,182 & 130,765 & 107,897 \\
\hline 5 & 29.25 & 223,232 & 149,375 & 131,958 & 107,897 \\
\hline 6 & 29.50 & 224,924 & 150,569 & 133,152 & 107,897 \\
\hline
\end{tabular}

Table 2. The Value of Storage Capacity

\begin{tabular}{|c|c|c|c|c|c|}
\hline & Active & Q $26 \%$ & Q $50.7 \%$ & Q 75.3\% & Q $97.3 \%$ \\
\hline No. & $\begin{array}{l}\text { Storage } \\
\left(10^{6} \mathrm{~m}^{3}\right)\end{array}$ & $\begin{array}{l}\text { Value } \\
\left(\mathrm{rp} / \mathrm{m}^{3}\right)\end{array}$ & $\begin{array}{l}\text { Value } \\
\left(\mathrm{rp} / \mathrm{m}^{3}\right)\end{array}$ & $\begin{array}{l}\text { Value } \\
\left(\mathrm{rp} / \mathrm{m}^{3}\right)\end{array}$ & $\begin{array}{l}\text { Value } \\
\left(\mathrm{rp} / \mathrm{m}^{3}\right)\end{array}$ \\
\hline 1 & 28.26 & 6,766 & 4,775 & 4,775 & 0 \\
\hline 2 & 28.50 & 6,766 & 4,775 & 4,775 & 0 \\
\hline 3 & 28.75 & 6,766 & 4,775 & 4,775 & 0 \\
\hline 4 & 29.00 & 6,766 & 4,775 & 4,775 & 0 \\
\hline 5 & 29.25 & 6,766 & 4,775 & 4,775 & 0 \\
\hline
\end{tabular}

Constraint of additional water supply from weir: $T_{i} \leq D_{i}(24$ constraints $)$

With $D_{i}$ is the potential additional water supply from weir in period $i$.

Constraint of reservoir active storage capacity: $\mathrm{S}_{\mathrm{i}+1} \leq \mathrm{Ca}$ (23 constraints)

With $\mathrm{Ca}$ is the reservoir active storage capacity.

Total of the four groups of the system constraints are 95 .

\section{RESULT AND DISCUSSION}

The results of the solutions of the linear programming optimization models can be seen in the Table

Based on the values of the benefit of storage (Table 1), the values of additional storage can be estimated via dividing the incremental benefit by the incremental storage. These values represent how much gain can be achieved by adding more storage capacity to a current active storage with certain condition of inflow dependability. The result of calculation of value of storage capacity can be seen in the Table 2 .
The reservoir active storage capacity is 28.26 million $\mathrm{m}^{3}$. For the purpose of estimating the value of incremental storage capacity, the original value is added by about 0.25 million $\mathrm{m}^{3}$ for 5 times. In Table 2, the value of storage capacity is seemed to be constant with the increasing storage capacity. But actually, the value of storage capacity will decline and eventually become zero at a certain storage capacity. These zero-values storage capacities for Q26\% is at 50.00 million $\mathrm{m}^{3}$, for Q50.7\% is at 34.48 million $\mathrm{m}^{3}$, for $\mathrm{Q} 75.3 \%$ is at 30.59 million $\mathrm{m}^{3}$, and for $\mathrm{Q} 97.3 \%$ is at 14.08 million $\mathrm{m}^{3}$. Thus, for the inflow condition of Q97.3\%, the actual storage capacity of 28.26 million $\mathrm{m}^{3}$ is already too large.

\section{CONCLUSION}

In the dry year (inflow dependability of $97.3 \%$ ), there is no value for the additional storage capacity, but in the wetter years, there are significant values for adding more storage capacity. This information can be useful in the further developments of the project. 


\section{Acknowledgements}

The authors are expressing their gratitude to all parties who have contribution in completing this study. Especially the authors want to express many thanks to the Dean of Faculty of Engineering Universitas Brawijaya for the much needed support in carrying out of this study.

\section{REFERENCES}

D. Wisser, S. Frolking, S. Hagen, and M.F.P. Bierkens, 2013, Beyond Peak Reservoir Storage? A Global Estimate of Declining Water Storage Capacity in Large Reservoirs, Water Resour. Res., 49 , 5732-5739 doi: $10.1002 /$ wrcr. 20452.

Kamphuis, J. and Meerse, C., 2017, Integrated Sediment Management in Rivers and Reservoirs, American Journal in Civil Engineering, Science Publishing Group, 5(6): 315-319.

Issa, I.E., Al-Ansari, N., Sherwany, G., and Knutsson, S, 2013, Sedimentation Processes and Useful Life of Mosul Dam Reservoir, Iraq, Engineering, Scientific Research. 5: 779-784.

Khadatare, M.Y. and Jedhe, S.H., 2017, Sediment Assessment of UJJANI Reservoir in Maharashtra by using Remote Sensing Technique, IRJET, 4(8): 12551258.

Patel, A. and Katiyar. S.K., 2014, Prediction of Water Demand and Water Storage Capacity of Municipal System by using Geospatial
Techniques, Journal of Geomatics, Indian Society of Geomatics, 8(1) April 2014: 78-85.

Nobre, C.A., Marengo, J.A., Seluchi, M.E., Cuartas, L.A., and Lincoln, M.A., 2016, Some Characteristics and Impacts of the Drought and Water Crisis in Southeastern Brazil during 2014 and 2015, Journal of Water Resource and Protection, Scientific Research Publishing, 8:252-262.

Tshikolomo, K.A., Walker, S., and Nesamvuni, A.E., 2013, Prospect for Developing Water Storage through Analysis of Runoff and Storage Capacity of Limpopo and Luvuvhu-Letaba Water Management Areas of South Africa, International Journal of Applied Science and Technology, 3(3) March 2013: 70-79 .

P. Deeprasertkul, 2015, Linear Programming for Optimal Reservoir Operation of Chao Phraya River Basin, IJIRSET, 4, 9: 8054-8063 doi: 15680/IJIRSET.2015.0409008.

Wesli, 2015, Operation Planning Reservoir with Linear Programming Optimization Model for Water Demand of the Community In Aceh Besar District, Indonesian Journal of Geography, Faculty of Geography UGM, 47(1):99-106.

Difallah, W., Benahmed, K., Draoui, B., and Bounaama, F., 2017, Linear Optimization Model for Efficient Use of Irrigation Water, International Journal of Agronomy, Hindawi, Volume 2017, Article ID 5353648. 